\title{
PENGARUH CITRA PERUSAHAAN, PELAYANAN, DAN PRODUK TERHADAP KEPUTUSAN PEMBELIAN KONSUMEN PADA MASTER CASH \& CREDIT KOTA PINANG
}

\author{
Siti Lam'ah Nasution \\ Sekolah Tinggi Ilmu Ekonomi (STIE) Labuhanbatu, Rantauprapat - Sumatera Utara
}

\begin{abstract}
ABSTRAK
Tujuan penelitian ini adalah untuk mengetahui pengaruh citra perusahaan, pelayanan, dan produk terhadap keputusan pembelian konsumen pada Master Cash \& Credit Kota Pinang. Sampel yang digunakan dalam penelitian ini adalah konsumen Master Cash \& Credit Kota Pinang sebanyak 96 orang dengan menggunakan rumus Wibisono. Alat analisis yang digunakan dalam penelitian ini adalah regresi linear berganda, uji parsial (uji t), dan uji simultan (uji F). Berdasarkan hasil uji parsial (Uji t) menunjukkan bahwa citra perusahaan berpengaruh positif dan tidak signifikan terhadap keputusan pembelian konsumen, sedangkan pelayanan dan produk berpengaruh positif dan signifikan terhadap keputusan pembelian konsumen pada Master Cash \& Credit Kota Pinang. Berdasarka hasil uji simultan (uji F) menunjukkan bahwa citra perusahaan, pelayanan, dan produk secara bersama-sama berpengaruh positif dan signifikan terhadap keputusan pembelian konsumen pada Master Cash \& Credit Kota Pinang. Keputusan pembelian dapat dijelaskan oleh citra perusahaan, pelayanan, dan produk sebesar $65,1 \%$. Sedangkan sisanya $34,9 \%$ dapat dijelaskan oleh faktor lain yang tidak diteliti oleh penelitian ini.
\end{abstract}

Kata Kunci : Citra perusahaan, Pelayanan, Produk, Keputusan pembelian

\section{PENDAHULUAN}

Master Cash \& Credit merupakan perusahaan retail consumer yang menjual produkproduk elektronik dan furniture secara tunai (cash) dan kredit. Dalam usaha memenangkan persaingan bisnis pada era teknologi yang sangat ketat ini, kualitas produk bukan lagi satusatunya menjadi komoditas yang dapat dibanggakan, karena setiap pelaku bisnis pasti selalu berusaha dan dapat membuat produk yang berkualitas tinggi. Kualitas merupakan suatu standar yang dengan mudah dan cepat dapat dimiliki oleh siapa saja. Satu-satunya atribut yang sulit ditiru adalah citra (image) yang kuat yang terekam dalam benak konsumen. Pembentukan citra atau image yang baik di benak konsumen dapat menjadi kekuatan peritel dalam memperebutkan calon konsumen potensial dan mempertahankan konsumen yang ada.

Citra perusahaan (company image) merupakan keseluruhan persepsi terhadap suatu perusahaan yang dibentuk dengan memproses informasi dari berbagai sumber setiap waktu. Citra perusahaan dibangun berdasarkan pemikiran ataupun pengalaman yang dialami seseorang terhadap perusahaan yang bersangkutan. Citra perusahaan juga merupakan keseluruhan dari persepsi konsumen mengenai perusahaan tersebut, atau bagaimana cara mereka memandangnya yang mungkin tidak serupa dengan identitas perusahaan. Oleh karena itulah membangun kepercayaan konsumen melalui citra perusahaan yang baik sangatlah penting untuk meraih pangsa pasar yang diharapkan oleh perusahaan. Setiap perusahaan berusaha untuk menarik perhatian (calon) konsumen dengan berbagai cara, salah satunya dengan membangun citra perusahaan yang baik dimata konsumen. 
Master Cash \& Credit merupakan perusahaan retail consumer yang menjual produkproduk elektronik dan furniture dari berbagai merek (brand). Untuk produk elektronik, misalnya TV, mesin cusi, lemari es, AC, dan sebagainya, terdapat beberapa merek elektronik yang dijual di Master Cash \& Credit antara lain merek LG, Toshiba, Sharp, Samsung, Panasonic, Polytron. Sedangkan untuk produk Furnitur, misalnya kursi, sofa, spring bed, dan lain-lain, ada beberapa merek antara lain, Olympic, Chitos, Alga, Caesar, dan sebagainya.

Keputusan pembelian merupakan perilaku yang dilakukan oleh individu-individu yang berbeda. Individu adalah konsumen yang berpotensial untuk membeli suatu produk tertentu yang ditawarkan oleh perusahaan atau ditemukan dipasar. Konsumen bebas memilih produk yang dibutuhkan atau diinginkan. Pasar sebagai pihak yang menawarkan berbagai produk kepada konsumen harus dapat menganalisis faktor-faktor yang mempengaruhi konsumen dalam pembelian, mengetahui persepsi konsumen dalam menilai sesuatu yang berpengaruh dalam pembelian sehingga pemasar dapat merancang strategi pemasaran yang sesuai dengan keinginan konsumen.

Meskipun Master Cash \& Credit memiliki beberapa pesaing yang yang ada di Kota Pinang, seperti Colombus dan Maestro, Master Cash \& Credit memiliki keunggulankeunggulan yang dapat menjadi positioning-nya sehingga kehadirannya dapat diterima dan terus berkembang. Salah satu kunci sukses yang dimiliki Master Cash \& Credit adalah dengan memberikan pelayanan yang maksimal kepada customer. Pelayanan yang diberikan Master Cash \& Credit antara lain bunga kredit yang ringan, tenor yang lama (24 bulan), jam buka toko sampai malam, layanan online shop, Full Range of Choice, Free Parking, dan Self Service yang tentunya berbeda dari usaha ritel sejenis lainnya. Master Cash \& Credit juga bekerja sama dengan pihak lain seperti bank Mandiri, BRI, dan BNI dalam penyediaan mesin EDC untuk transaksi menggunakan kartu debet atau kartu kredit dan penyediaan fasilitas ATM. Master Cash \& Credit menawarkan produknya dengan berbagai alternatif pilihan merek sehingga memudahkan para pelanggan memilih produk yang dibutuhkannya. Tidak hanya menawarkan merek-merek lokal saja, Master Cash \& Credit juga menyediakan berbagai produk impor (Full Range of Choice). Brastagi Supermarket menyediakan fasilitas parkir luas dan gratis yang tentu saja memberikan kemudahan bagi para pelanggannya untuk datang dan berbelanja (Free Parking), serta kebebasan dan kemudahan bagi para pelanggannya untuk berbelanja (Self-Service).

\section{TINJAUAN PUSTAKA}

Kaitan antara citra (image) dengan minat beli dikemukakan Habul dalam Dinawan (2010) bahwa citra (image) akan berpengaruh langsung terhadap tingginya minat beli terhadap suatu perkembangan produk. Hasibuan (2012) juga menyatakan bahwa perkembangan pasar yang demikian pesat mendorong konsumen untuk lebih memperhatikan citra (image) dibandingkan karakteristik fisik suatu produk dalam memutuskan pembelian. Menurut Aaker dalam Hasibuan (2012), terdapat 4 hal pokok yang harus diperhatikan dalam membentuk sebuah brand, yaitu recognition, reputation, affinity, dan brand loyalty. Dalam penelitian ini penulis akan menggunakan dimensi recognition, yaitu tingkat dikenalnya perusahaan Master Cash \& Credit oleh konsumen dan reputation yaitu tingkat atau status yang cukup tinggi bagi Master Cash \& Credit.

Menurut Kotler (2009:83), pelayanan adalah setiap tindakan atau kegiatan yang dapat ditawarkan oleh suatu pihak kepada pihak lain, yang pada dasarnya tidak berwujud dan tidak mengakibatkan kepemilikan apapun.

Kualitas produk merupakan faktor yang berpengaruh terhadap keputusan pembelian. Kualitas produk merupakan kemampuan produk untuk menunjukkan berbagai fungsi 
termasuk di dalamnya ketahanan, handal, ketepatan, dan kemudahan dalam penggunaan (Kotler dan Armstrong, 2007:346). Semakin baik kualitas produk maka akan meningkatkan minat konsumen untuk melakukan pembelian.

Peritel adalah pengusaha yang menjual barang atau jasa secara eceran kepada masyarakat sebagai konsumen (Ma'ruf, 2006:71). Para peritel ini menggabungkan unsurunsur bauran eceran untuk menarik pasar sasaran dan dapat memenuhi harapan-harapan para pelanggan, sehingga akan menciptakan keputusan pembelian.

Menurut Kotler (2009:83), pelayanan adalah setiap tindakan atau kegiatan yang dapat ditawarkan oleh suatu pihak kepada pihak lain, yang pada dasarnya tidak berwujud dan tidak mengakibatkan kepemilikan apapun.

Kualitas produk merupakan faktor yang berpengaruh terhadap keputusan pembelian. Kualitas produk merupakan kemampuan produk untuk menunjukkan berbagai fungsi termasuk di dalamnya ketahanan, handal, ketepatan, dan kemudahan dalam penggunaan (Kotler dan Armstrong, 2007:346). Semakin baik kualitas produk maka akan meningkatkan minat konsumen untuk melakukan pembelian.

Menurut Kotler dan Amstrong (2008:179) keputusan pembelian merupakan hasil dari suatu proses yang terdiri dari lima tahap : pengenalan kebutuhan, pencarian informasi, evaluasi alternatif, keputusan pembelian dan perilaku pasca pembelian.

\section{METODE}

\section{Populasi dan Sampel}

Yang menjadi populasi dalam penelitian ini adalah konsumen Master Cash \& Credit yang jumlahnya tidak dapat ditentukan secara pasti.

Menurut Sugiyono (2010 : 118) sampel adalah bagian dari jumlah dan karakterisitik yang dimiliki oleh populasi tersebut. Dapat disimpulkan bahwa sampel merupakan bagian dari populasi yang mempunyai karakteristik dan sifat yang mewakili seluruh populasi yang ada.

Karena populasi dalam penelitian ini tidak diketahui jumlahnya, menurut Wibisono (dalam Riduwan dan Akdon, 2013 : 255) rumus dalam menghitung sampel pada populasi yang tidak diketahui adalah sebagai berikut :

Keterangan :

$$
n=\left[\frac{Z_{\alpha / 2} \cdot \delta}{\varepsilon}\right]^{2}
$$

$$
\begin{aligned}
\mathrm{n} & =\text { jumlah sampel } \\
\mathrm{Z} \alpha & =\text { nilat tabel } \mathrm{Z}=0,05 \\
\delta & =\text { standar deviasi } \\
\varepsilon & =\text { margin error }
\end{aligned}
$$

Dengan demikian, jumlah sampel dalam penelitian ini adalah :

$$
n=\left[\frac{Z_{\alpha / 2} \cdot \delta}{\varepsilon}\right]^{2}=\left[\frac{(1,96)(0,25)}{0,05}\right]^{2}=96,04 \approx 96 \text { orang }
$$

\section{Teknik Pengumpulan Data}

Dalam penelitian ini metode yang digunakan dalam pengumpulan data adalah :

1. Wawancara

Wawancara adalah tekhnik pengumpulan data dengan mengadakan wawancara langsung kepada informan untuk memperoleh informasi berkenaan dengan yang diteliti.

2. Daftar Pertanyaan (Kuesioner) 
Kuisioner adalah tekhnik pengumpulan data dengan cara memberikan pertanyaan secara tertulis kepada responden atau objek yang diteliti untuk dijawab sehingga kita dapat memperoleh data yang diharapkan.

3. Studi Pustaka

Studi pustaka adalah tekhnik pengumpulan data dengan cara menggunakan buku-buku, jurnal dan internet yang berhubungan dengan masalah yang diteliti.

\section{Metode Analisis Data}

a. Metode Analisis Deskriptif, merupakan cara merumuskan dan menafsirkan data yang ada sehingga memberikan gambaran yang jelas melalui pengumpulan, penyusunan, dan penganalisisan data sehingga dapat diketahui gambaran data yang sedang diteliti. Data diperoleh dari data primer berupa kuesioner yang telah diisi oleh sejumlah responden penelitian.

b. Analisis Regresi Linier Berganda

Metode analisis regresi linier berganda digunakan untuk mengetahui berapa besar pengaruh variabel independen (citra perusahaan, pelayanan, dan produk) terhadap variabel dependen (keputusan pembelian). Data diolah secara statistik untuk keperluan analisis dan pengujian hipotesis dengan menggunakan alat bantu program SPSS 20.0 for windows.

Adapun bentuk umum persamaan regresi yang digunakan adalah sebagai berikut:

$$
\begin{aligned}
& \mathbf{Y}=\mathbf{a}+\mathbf{b}_{1} \mathbf{X}_{1}+\mathbf{b}_{2} \mathbf{X}_{2}+\mathbf{b}_{3} \mathbf{X}_{3}+e \\
& \text { Keterangan : } \\
& \mathrm{Y}=\text { Keputusan pembelian } \\
& \text { a } \quad=\text { Konstanta } \\
& \mathrm{b}_{1}, \mathrm{~b}_{2}, \mathrm{~b}_{3}=\text { Koefisien regresi } \\
& \mathrm{X}_{1} \quad=\text { Citra perusahaan } \\
& \mathrm{X}_{2} \quad=\text { Pelayanan } \\
& \mathrm{X}_{3} \quad=\text { Produk } \\
& e \quad=\text { Standar error }
\end{aligned}
$$

1) Uji Signifikansi Parsial (Uji t)

Uji t menentukan seberapa besar pengaruh variabel independen $(\mathrm{X})$ secara parsial terhadap variabel dependen (Y). Kriteria pengujian adalah :

- $\mathrm{H}_{0}: \mathrm{b}_{1}=\mathrm{b}_{2}=\mathrm{b}_{3}=0$, artinya secara parsial tidak terdapat pengaruh yang positif dan signifikan antara variabel independen $\left(\mathrm{X}_{1}, \mathrm{X}_{2}\right.$, dan $\left.\mathrm{X}_{3}\right)$ yaitu citra perusahaan, pelayanan, dan produk terhadap variabel dependen $(\mathrm{Y})$ yaitu keputusan pembelian.

- Ha $: b_{1} \neq b_{2} \neq b_{3} \neq 0$, artinya secara parsial terdapat pengaruh yang positif dan signifikan antara variabel independen $\left(\mathrm{X}_{1}, \mathrm{X}_{2}\right.$, dan $\left.\mathrm{X}_{3}\right)$ yaitu citra perusahaan, pelayanan, dan produk terhadap variabel dependen $(\mathrm{Y})$ yaitu keputusan pembelian.

Kriteria pengambilan keputusan :

- $\mathrm{H}_{0}$ diterima jika thitung $<\mathrm{t}_{\text {tabel }}$ pada $\alpha=5 \%$.

- $\mathrm{H}_{0}$ ditolak jika $\mathrm{t}_{\text {hitung }}>\mathrm{t}_{\text {tabel }}$ pada $\alpha=5 \%$.

2) Uji Signifikansi Simultan (Uji-F)

Uji-F pada dasarnya menunjukkan apakah semua variabel independen yang dimasukkan dalam model mempunyai pengaruh secara bersama-sama terhadap variabel dependen. Kriteria pengujian adalah : 
- $\mathrm{H}_{0}: \mathrm{b}_{1}=\mathrm{b}_{2}=\mathrm{b}_{3}=0$, artinya secara bersama-sama tidak terdapat pengaruh yang positif dan signifikan antara variabel independen $\left(\mathrm{X}_{1}, \mathrm{X}_{2}\right.$, dan $\left.\mathrm{X}_{3}\right)$ yaitu citra perusahaan, pelayanan, dan produk terhadap variabel dependen $(\mathrm{Y})$ yaitu keputusan pembelian.

- Ha $: b_{1} \neq b_{2} \neq b_{3} \neq 0$, artinya secara bersama-sama terdapat pengaruh yang positif dan signifikan antara variabel independen $\left(\mathrm{X}_{1}, \mathrm{X}_{2}\right.$, dan $\left.\mathrm{X}_{3}\right)$ yaitu citra perusahaan, pelayanan, dan produk terhadap variabel dependen $(\mathrm{Y})$ yaitu keputusan pembelian.

Kriteria pengambilan keputusan :

- $\mathrm{H}_{0}$ diterima jika $\mathrm{F}_{\text {hitung }}<\mathrm{F}_{\text {tabel }}$ pada $\alpha=5 \%$.

- $\mathrm{H}_{0}$ ditolak jika $\mathrm{F}_{\text {hitung }}>\mathrm{F}_{\text {tabel }}$ pada $\alpha=5 \%$.

3) Koefisien Determinasi $\left(R^{2}\right)$

Koefisien determinasi $\left(R^{2}\right)$ pada intinya mengukur seberapa besar kemampuan model dalam menerangkan variabel dependen. Jika $R^{2}$ semakin besar (mendekati satu), maka dapat dikatakan bahwa hubungan variabel independen $\left(\mathrm{X}_{1}, \mathrm{X}_{2}\right.$, dan $\left.\mathrm{X}_{3}\right)$ adalah besar terhadap variabel dependen (Y). Hal ini berarti model yang digunakan semakin kuat untuk menerangkan hubungan variabel independen yang diteliti terhadap variabel dependen. Sebaliknya, jika $R^{2}$ semakin kecil (mendekati nol) maka dapat dikatakan bahwa hubungan variabel independen $\left(\mathrm{X}_{1}, \mathrm{X}_{2}\right.$, dan $\left.\mathrm{X}_{3}\right)$ terhadap variabel dependen $(\mathrm{Y})$ semakin kecil. Hal ini berarti model yang digunakan tidak kuat. Secara umum dapat dikatakan besarnya koefisien determinasi berganda $\left(R^{2}\right)$ berada diantara 0 dan 1 atau $0 \leq R^{2} \leq 1$.

\section{HASIL DAN PEMBAHASAN}

\section{Analisis Regresi Linear Berganda}

Analisis regresi linear berganda digunakan untuk mengetahui berapa besar pengaruh variabel bebas $\left(\mathrm{X}_{1}, \mathrm{X}_{2}, \mathrm{X}_{3}\right)$ terhadap variabel terikat $(\mathrm{Y})$. Maka untuk memperoleh hasil yang lebih akurat digunakan program software SPSS 20.0 for windows, maka dari Tabel coefficient dihasilkan output sebagai berikut :

Tabel 1

Hasil Regresi Linear Berganda Coefficients $^{\mathrm{a}}$

\begin{tabular}{|c|c|c|c|c|c|}
\hline \multirow[t]{2}{*}{ Model } & \multicolumn{2}{|c|}{ Unstandardized Coefficients } & Standardized & \multirow[t]{2}{*}{$\mathrm{t}$} & \multirow[t]{2}{*}{ Sig. } \\
\hline & $B$ & Std. Error & Beta & & \\
\hline \multirow{4}{*}{$\begin{array}{l}\text { Citra pe } \\
\text { Pelayar } \\
\text { Produk }\end{array}$} & 0,625 & 0,262 & & 0,287 & 201 \\
\hline & , 087 & 076 & ,073 & 1,134 & 260 \\
\hline & ,338 & 071 & , 330 & 4,731 & , 000 \\
\hline & 556 &, 065 & 585 & 8,607 & ,000 \\
\hline
\end{tabular}

a. Dependent Variable: Kep.pembelian

Sumber : Hasil Pengolahan SPSS, 2016

Berdasarkan hasil pengolahan data seperti terlihat pada Tabel 4.9 Kolom

Unstandardized Coefficients bagian B nilai koefien regresi masing-masing variabel, yaitu :

1) Konstanta (a) $=0,625$. Ini berarti bahwa apabila variabel citra perusahaan, pelayanan, dan produk dianggap tidak ada, maka keputusan pembelian sebesar 0,625.

2) Koefisien $X_{1}\left(b_{1}\right)=0,087$. Ini berarti bahwa jika variabel citra perusahaan meningkat satu satuan dan variabel lainnya konstan, maka keputusan pembelian meningkat sebesar 0,087 .

3) Koefisien $X_{2}\left(b_{2}\right)=0,338$. Ini berarti bahwa jika variabel pelayanan meningkat satu satuan dan variabel lainnya konstan, maka keputusan pembelian meningkat sebesar 0,338 . 
4) Koefisien $X_{3}\left(b_{3}\right)=0,556$. Ini berarti bahwa jika variabel produk meningkat satu satuan dan variabel lainnya konstan, maka keputusan pembelian meningkat sebesar 0,556.

Berdasarkan hasil tersebut, maka persamaan regresi adalah :

\section{Pengujian Hipotesis}

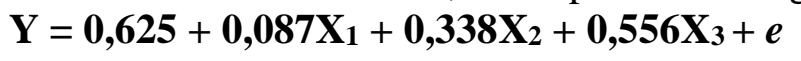

Hipotesis pada penelitian ini diuji dengan menggunakan uji signifikansi parsial (Uji t), uji signifikansi simultan (Uji F), dan koefisien determinasi $\left(R^{2}\right)$.

\section{a. Uji Signifikansi Parsial (Uji t)}

Uji $\mathrm{t}$ ini menunjukkan seberapa besar pengaruh variabel bebas (X) secara parsial/individu terhadap variabel terikat (Y). Uji t dilakukan dengan cara membandingkan nilai thitung dengan $t_{\text {tabel }}$ dengan kriteria pengambilan keputusan adalah :

- $\mathrm{H}_{0}$ diterima jika $\mathrm{t}_{\text {hitung }}<\mathrm{t}_{\text {tabel }}$ pada $\alpha=5 \%$.

- Ha diterima jika $t_{\text {hitung }}>t_{\text {tabel }}$ pada $\alpha=5 \%$.

Nilai thitung diperoleh dari pengolahan data SPSS 20.0 for Windows, kemudian akan dibandingkan dengan nilai $t_{\text {tabel }}$ pada tingkat $\alpha=5 \%$. Nilai $t_{\text {tabel }}$ yang digunakan adalah nilai distribusi t dengan derajat bebas (df) yaitu $\mathrm{df}=\mathrm{n}-\mathrm{k}=96-3=92$. Uji $\mathrm{t}_{\text {hitung }}$ yang dilakukan adalah uji dua arah maka $t_{\text {tabel }}$ yang digunakan adalah $t 5 \%$ atau $t_{0,05}(92)=1,66159$.

\section{Tabel 2}

\section{Hasil Uji Parsial (Uji t)}

Coefficients $^{a}$

\begin{tabular}{|c|c|c|c|c|c|}
\hline \multirow[t]{2}{*}{ Model } & \multicolumn{2}{|c|}{ Unstandardized Coefficients } & Standardized & \multirow[t]{2}{*}{$\mathrm{t}$} & \multirow[t]{2}{*}{ Sig. } \\
\hline & B & Std. Error & Beta & & \\
\hline \multirow{4}{*}{$\begin{array}{l}\text { Citra perusahaan } \\
\text { Pelayanan } \\
\text { Produk }\end{array}$} & 0,625 & 0,262 & & 0,287 & 201 \\
\hline & 087, & 076 & ,073 & 1,134 & 260 \\
\hline & ,338 & 071 & ,330 & 4,731 &, 000 \\
\hline &, 556 & 065 & 585 & 8,607 &, 000 \\
\hline
\end{tabular}

a. Dependent Variable: Kep.pembelian

Berdasarkan Tabel diatas, maka dapat dijelaskan sebagai berikut :

1) Untuk variabel citra perusahaan $\left(X_{1}\right)$, diperoleh nilai $t_{\text {hitung }}(1,134)<t_{\text {tabel }}(1,66159)$ dengan taraf signifikansi $0,260>0,05$. Hasil ini menunjukkan bahwa citra perusahaan berpengaruh positif tetapi tidak signifikan terhadap keputusan pembelian. Dengan demikian hipotesis ditolak.

2) Untuk variabel pelayanan $\left(X_{2}\right)$ diperoleh nilai thitung $(4,731)>t_{\text {tabel }}(1,66159)$ dengan taraf signifikansi $0,000<0,05$. Hasil ini menunjukkan bahwa pelayanan berpengaruh positif dan signifikan terhadap keputusan pembelian. Dengan demikian hipotesis dapat diterima.

3) Untuk variabel produk $\left(X_{3}\right)$ diperoleh nilai thitung $(8,607)>t_{\text {tabel }}(1,66159)$ dengan taraf signifikansi $0,000<0,05$. Hasil ini menunjukkan bahwa produk berpengaruh positif dan signifikan terhadap keputusan pembelian. Dengan demikian hipotesis dapat diterima.

\section{b. Uji Signifikansi Simultan (Uji F)}

Uji F (uji serentak) dilakukan untuk melihat secara bersama-sama pengaruh atau hubungan positif dan signifikan variabel bebas $\left(\mathrm{X}_{1}, \mathrm{X}_{2}\right.$, dan $\left.\mathrm{X}_{3}\right)$ berupa variabel citra perusahaan, pelayanan, dan produk dan variabel terikat (Y) berupa keputusan pembelian.

Kriteria pengambilan keputusan adalah :

- $\mathrm{H}_{0}$ diterima jika $\mathrm{F}_{\text {hitung }}<\mathrm{F}_{\text {tabel }}$ pada $\alpha=5 \%$.

- Ha diterima jika $F_{\text {hitung }}>F_{\text {tabel }}$ pada $\alpha=5 \%$.

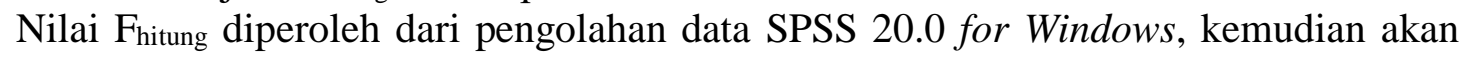
dibandingkan dengan nilai $\mathrm{F}_{\text {tabel }}$ pada tingkat $\alpha=5 \%$. Nilai $\mathrm{F}_{\text {tabel }}$ yang digunakan adalah nilai 
distribusi $\mathrm{F}$ dengan derajat bebas $(\mathrm{df})$, yaitu df $1=4-1=3$, dan df $2=96-4=92$. Maka $\mathrm{F}_{\text {tabel }}$ yang digunakan adalah nilai $\mathrm{F}(3: 92)=2,70$.

\section{Tabel 3}

Hasil Uji Simultan (Uji F) ANOVA $^{\mathrm{a}}$

\begin{tabular}{|rl|r|r|r|r|r|}
\hline Model & & Sum of Squares & df & Mean Square & F & Sig. \\
\hline \multirow{2}{*}{1} & Regression & 97,564 & 3 & 32,521 & 60,117 &, $000^{\mathrm{b}}$ \\
& Residual & 49,769 & 92 &, 541 & & \\
& Total & 147,333 & 95 & & & \\
\hline
\end{tabular}

a. Dependent Variable: Kep.pembelian

b. Predictors: (Constant), Citra perusahaan, Produk, Pelayanan

Berdasarkan Tabel diatas dapat diketahui bahwa $F_{\text {hitung }}(60,117)>F_{\text {tabel }}(2,70)$ dengan taraf signifikansi $0,000<0,05$. Hasil ini menunjukkan bahwa secara bersama-sama variabel citra perusahaan, pelayanan, dan produk berpengaruh positif dan signifikan terhadap keputusan pembelian. Dengan demikian hipotesis dapat diterima.

\section{c. Koefisien Determinasi $\left(\boldsymbol{R}^{2}\right)$}

Pengujian koefisien determinasi $\left(R_{2}\right)$ bertujuan untuk mengetahui seberapa besar kemampuan variabel bebas menjelaskan variabel terikat. Dalam output SPSS, koefisien determinasi terletak pada tabel Model Summary dan tertulis $R$ Square. Namun untuk regresi linear berganda sebaiknya menggunakan nilai $R$ Square yang sudah disesuaikan atau tertulis Adjusted $R$ Square, karena disesuaikan dengan jumlah variabel bebas dalam penelitian. Nilai $R$ Square dikatakan baik jika di atas 0,5 karena nilai $R$ Square berkisar antara 0 sampai 1.

\section{Tabel 4}

Koefisien Determinasi Model Summary

\begin{tabular}{|l|r|r|r|r|}
\hline Model & $\mathrm{R}$ & $\mathrm{R}$ Square & $\begin{array}{c}\text { Adjusted R } \\
\text { Square }\end{array}$ & $\begin{array}{c}\text { Std. Error of the } \\
\text { Estimate }\end{array}$ \\
\hline 1 &, $814^{\mathrm{a}}$ &, 662 &, 651 &, 736 \\
\hline
\end{tabular}

a. Predictors: (Constant), Citra perusahaan, Produk, Pelayanan

Berdasarkan Tabel diatas dapat dijelaskan sebagai berikut :

1) Nilai $R=0,814$ berarti hubungan antara citra perusahaan $\left(\mathrm{X}_{1}\right)$, pelayanan $\left(\mathrm{X}_{2}\right)$, dan produk $\left(\mathrm{X}_{3}\right)$ terhadap keputusan pembelian $(\mathrm{Y})$ sebesar $81,4 \%$. Artinya hubungan antar variabel sangat kuat.

2) Nilai Adjusted $R$ square sebesar 0,651 berarti $65,1 \%$ keputusan pembelian dapat dijelaskan oleh variabel citra perusahaan $\left(\mathrm{X}_{1}\right)$, pelayanan $\left(\mathrm{X}_{2}\right)$, dan produk $\left(\mathrm{X}_{3}\right)$. Sedangkan sisanya $34,9 \%$ dapat dijelaskan oleh faktor lain yang tidak diteliti oleh penelitian ini.

3) Standard Error of Estimated (standar deviasi) bernilai 0,736 yang berarti model regresi dinilai baik, karena semakin kecil standar deviasi berarti model akan semakin baik.

\section{Pembahasan}

\section{a. Pengaruh Citra Perusahaan Terhadap Keputusan Pembelian}

Berdasarkan jawaban responden, diketahui bahwa Master Cash \& Credit telah dikenal oleh masyarakat sebagai perusahaan yang menjual produk-produk elektronik dengan barbagai merek terkenal. Master Cash \& Credit menjual produk-produknya secara tunai (cash) dan kredit.

Berdasarkan hasil uji-t, maka variabel citra perusahaan berpengaruh positif tetapi tidak signifikan terhadap keputusan pembelian konsumen pada Master Cash \& Credit Kota Pinang. Hal ini terlihat dari nilai $t_{\text {hitung }}(1,134)<t_{\text {tabel }}(1,66159)$ dan taraf signifikan $(0,260)>$ 
0,05. Hal ini berarti bahwa citra perusahaan tidak terlalu mempengaruhi konsumen dalam melakukan pembelian di master Cash \& Credit Kota Pinang.

Membangun citra perusahaan memang cukup sulit, tetapi sekali terbentuk maka tidak mudah untuk mengubahnya. Keterkaitan pada suatu brand akan lebih kuat apabila dilandasi pada banyak pengalaman atau penampakan untuk mengkomunikasikannya. Berbagai asosiasi yang diingat konsumen dapat dirangkai sehingga membentuk citra tentang perusahaan.

Hasil penelitian ini bertolak belakang dengan penelitian yang dilakukan Penelitian Hasibuan (2012) yang berjudul Pengaruh Harga, Kualitas Produk, dan Citra Merek Terhadap Keputusan Pembelian Kecap Manis Merek Bango (Studi Kasus Pada Ibu Rumah Tangga di Komplek Villa Mutiara Johor II dan Taman Johor Mas), dimana hasil penelitian tersebut menyatakan bahwa citra merek merupakan variabel yang dominan mempengaruhi keputusan pembelian.

\section{b. Pengaruh Pelayanan Terhadap Keputusan Pembelian}

Berdasarkan jawaban responden yang diperoleh, diketahui bahwa pelayanan Master Cash \& Credit sudah cukup baik, dimana sudah tersedia layanan informasi bagi konsumen, pramuniaga dan kasir yang cekatan dalam melayani konsumen.

Berdasarkan hasil uji-t, maka variabel harga berpengaruh positif dan signifikan terhadap keputusan pembelian konsumen pada Master Cash \& Credit Kota Pinang. Hal ini terlihat dari nilai $t_{\text {hitung }}(4,731)>t_{\text {tabel }}(1,66159)$ dan taraf signifikan $(0,000)<0,05$. Hal ini berarti pelayanan berpengaruh dalam keputusan pembelian.

Hasil penelitian ini sejalan dengan penelitian yang dilakukan oleh Penelitian Sebayang (2012) yang berjudul Faktor-faktor Yang Mempengaruhi Kaum Ibu Melakukan Pembelian di Matahari Department Store Plaza Medan Fair Medan, dimana hasil penelitian tersebut menyatakan secara parsial variabel pelayanan merupakan variabel yang paling dominan mempengaruhi kaum ibu melakukan pembelian pada Matahari Department Store Plaza Medan Fair Medan.

\section{c. Pengaruh Produk Terhadap Keputusan Pembelian}

Berdasarkan hasil uji-t, maka variabel produk berpengaruh positif dan signifikan terhadap keputusan pembelian konsumen pada Master Cash \& Credit Kota Pianang. Hal ini terlihat dari nilai $t_{\text {hitung }}(8,607)>t_{\text {tabel }}(1,66159)$ dan taraf signifikan $(0,000)<0,05$. Variabel produk juga berpengaruh paling dominan terhadap keputusan pembelian konsumen.

Hasil penelitian ini sejalan dengan penelitian yang dilakukan oleh Penelitian Sebayang (2012) yang berjudul Faktor-faktor Yang Mempengaruhi Kaum Ibu Melakukan Pembelian di Matahari Department Store Plaza Medan Fair Medan, dimana hasil penelitian tersebut menyatakan secara parsial variabel produk berpengaruh terhadap keputusan pembelian.

\section{d. Pengaruh Citra Perusahaan, Pelayanan, dan Produk Terhadap Keputusan Pembelian}

Berdasarkan hasil uji F diketahui bahwa Citra perusahaan, Pelayanan, dan Produk secara bersama-bersama berpengaruh positif dan signifikan terhadap keputusan pembelian konsumen pada Master Cash \& Credit Kota Pinang. Hal ini dapat dilihat dari nilai $F_{\text {hitung }}$ $(60,117)>F_{\text {tabel }}(2,70)$ dan taraf signifikansi $0,000<0,05$. Berdasarkan hasil uji determinasi diketahui bahwa keputusan pembelian dapat dijelaskan oleh Citra perusahaan, Pelayanan, dan Produk sebesar $65,1 \%$. Sedangkan sisanya $34,9 \%$ dapat dijelaskan oleh faktor lain yang tidak diteliti oleh penelitian ini.

\section{KESIMPULAN DAN SARAN \\ 1. Kesimpulan}


Berdasarkan hasil analisis yang telah dilakukan, maka dapat diambil beberapa kesimpulan sebagai berikut :

1. Citra perusahaan secara parsial berpengaruh positif dan tidak signifikan terhadap keputusan pembelian konsumen pada Master Cash \& Credit Kota Pinang.

2. Pelayanan secara parsial berpengaruh positif dan signifikan terhadap keputusan pembelian konsumen pada Master Cash \& Credit Kota Pinang.

3. Produk secara parsial berpengaruh positif dan signifikan terhadap keputusan pembelian konsumen pada Master Cash \& Credit Kota Pinang.

4. Keputusan pembelian dapat dijelaskan oleh Citra perusahaan, Pelayanan, dan Produk sebesar $65,1 \%$. Sedangkan sisanya $34,9 \%$ dapat dijelaskan oleh faktor lain yang tidak diteliti oleh penelitian ini.

\section{Saran}

Berdasarkan kesimpulan diatas, peneliti memberikan saran sebagai berikut:

1. Master Cash \& Credit hendaknya senantiasa memperhatikan pelayanan kepada konsumen. Pelayanan yang perlu ditingkatkan seperti lahan parkir yang masih kurang luas sehingga tidak dapat menampung kendaraan khususnya mobil pada jam malam dan terutama ketika weekend dan menjelang hari raya. Tak jarang juga kendaraan pengunjung terpaksa diparkir diluar lahan parkir, yaitu di pinggir jalan. Hal ini menimbulkan ketidaknyamanan bagi pengunjung yang harus selalu memikirkan keamanan kendaraannya.

2. Master Cash \& Credit hendaknya mempertimbangkan bunga kredit yang diberikan kepada konsumen, khususnya dalam situasi ekonomi yang sulit seperti sekarang ini.]

3. Bagi penelitian selanjutnya lebih baik jika menambahkan variabel-variabel yang tidak diteliti dalam penelitian yang sama agar diperoleh hasil yang lebih maksimal.

\section{DAFTAR PUSTAKA}

Arisutha, Damartaji. 2006. Dimensi Kualitas Pelayanan. Jakarta : PT. Gramedia Pustaka.

Boyd, Walker dan Larreche. 2006. Manajemen Pemasaran : Suatu Pendekatan Strategis dengan Orientasi Global, Edisi Kedua.Jakarta : Erlangga.

Garspersz, Vincent. 2006. Total Quality Management. Jakarta : Penerbit Erlangga.

Ghozali, Imam. 2009. Aplikasi Analisis Multivariate dengan Program SPSS. Semarang : Badan Penerbit Universitas Diponegoro.

Hasibuan, Nurlisa. 2012. "Pengaruh Harga, Kualitas Produk, dan Citra Merek Terhadap Keputusan Pembelian Kecap Manis Merek Bango (Studi Kasus Pada Ibu Rumah Tangga di Komplek Villa Mutiara Johor II dan Taman Johor Mas Medan)". Skripsi. Fakultas Ekonomi USU Medan.

Kertajaya, Hermawan. 2009. Perjalanan Pemikiran Konsep Pemasaran. Jakarta : PT. Gelora Aksara Pratama.

Kotler, Philip dan Amstrong, Gary. 2007. Dasar-Dasar Pemasaran. Edisi Kesembilan. Cetakan Kedua. Jakarta: PT. Indeks.

Kedelapan. Jakarta : Erlangga. 2008. Prinsip-prinsip Pemasaran. Jilid Satu. Edisi

Kotler, Phillip, 2008. Manajemen Pemasaran Global. Jakarta : Salemba Empat. 2009. Manajemen Pemasaran. Jakarta : Erlangga.

Kuncoro, Mudrajad. 2009. Metode Riset untuk Bisnis \& Ekonomi (Edisi 3). Jakarta : Erlangga.

Margaretha, Farah. 2007. Kualitas Pelayanan : Teori dan Praktik. Jakarta : PT. Gramedia Pustaka. 
Martul, Shadiqqin. 2006. Implementasi Dimensi Kualitas Pelayanan. Jakarta : PT. Gramedia Pustaka.

Ma'ruf, Hendri. 2006. Pemasaran Ritel. Jakarta : PT Gramedia Pustaka Utama.

Mowen, Jhon C dan Minor, Michael. 2007. Perilaku Konsumen. Jakarta : Erlangga.

Riduwan dan Akdon. 2013. Rumus dan Data dalam Analisis Statistika. Bandung : Alfabeta.

Sebayang, Bastian. 2012. "Faktor-faktor Yang Mempengaruhi Kaum Ibu Melakukan

Pembelian di Matahari Department Store Plaza Medan Fair Medan”. Skripsi. Fakultas

Ekonomi USU Medan.

Setiadi, Nogroho J, 2010. Perilaku Konsumen. Jakarta : Kencana.

Sugiyono. 2010. Metode Penelitian Kuantitatif, Kualitatif dan $R \&$ D. Bandung : Alfabeta.

Sunyoto, Danang. 2012. Manajemen Sumber Daya Manusia. Yogyakarta : CAPS.

Sutojo. 2006. Membangun Citra Perusahaan. Jakarta : Damar Mulia Pustaka.

Tjiptono, Fandy. 2008. Strategi Pemasaran. Yogyakarta : Andi.

Tjiptono, Fandy dan Gregorius Chandra. 2011. Service Quality and Satisfaction. Edisi 3. Yogyakarta : Andi.

Tjiptono, Fandy dan Gregorius Chandra. 2012. Pemasaran Strategik. Yogyakarta : Andi.

Umar, Husein. 2010. Riset Pemasaran dan Perilaku Konsumen. Jakarta : Gramedia Pustaka Utama. 